\title{
Musical Experience Development Model Based on Service Design Thinking
}

\author{
Sunyoung Kim and Eui-Chul Jung \\ Human Environment and Design, Yonsei University, Seoul, Korea \\ kim_sunyoung@outlook.com, jech@yonsei.ac.kr
}

\begin{abstract}
After 2012, the number of Korean musical audience grew larger than 5 million, which is the starting point of popularization. Considering newcoming audiences and changing market environment, overall analysis of musical art management and customer-centered approach is needed. Performance experience process and details of musical service will be analyzed based on 5 principles of service design thinking. This paper will study purchase stages from musical perspective, analyze flow experience structure model and the relationship between different musical contents. This paper has the characteristic of basic study to enhance musical experience and suggest planning direction.
\end{abstract}

Keywords: Musical Experience, Service Design Thinking.

\section{Introduction}

Starting from Phantom of the Opera performed at LG Art Center in 2001, blockbuster musicals based on major halls made a huge success. Since then, domestic musical market has been led by producers with license. The resulting increase in the production cost raised ticket price, which led consumers of musicals to become multi-layered based on social class(Choi, 2006). This phenomenon shows that at that time musical was recognized as high culture, and was not easy for most people to experience.

The number of musical audience grew from 300 thousand in 2001 to 3 million in 2010, and at the same time, the market size expanded to 200 billion won from 10 billion won. Currently, in 2012, it is estimated that there are 7 million consumers and the market worth 250 to 300 billion won(Interpark, 2012). Current point of musical audience larger than 5 million can be seen as the starting point of popularization.

When performance market environment changes and develops, market participation of government, pubic organization, arts organization, performance planning agency, theater, company, audience, media and others will increase. This will change and complicate interests within those concerned. Substantial changes of each sectors will require further realization and understanding of such changes (Lee, 2002). Since the ratio of consumers who are not familiar with musicals is increasing, measures must be taken to answer their wants and needs as well as explaining to them the existing musical culture. 
Performance has the characteristics of different elements such as art products, expected products, and value-added products, various functions. That is why performance's match different product characteristics must be taken into consideration(Jang, 2007). Art products are closer to service than products, and both have intangibility, heterogeneity, inseparability and perishability. Due to intangibility, performance exists as a sound source or DVD as well as performance itself. Because performance exists at the moment when it is performed, each performance is not the same product, and because of this, production and consumption happen at the same time which enables various interactions with consumers during the consuming process. Moreover, after the performance starts, the economic value disappears(Lee, 2001; Yong, 2010). Expected products has the characteristic of first purchasing and later consuming, and value-added products has the characteristic of providing various services other than performance in order to maximize consumer satisfaction.

Performance also has the characteristic of experience goods, which elicit stable and continuous consumption when repeatedly experienced and emotional taste is formed(Lee, 2009). This means performance experience forms conscious and unconscious structure that connects to coming performances, instead of ending as separate projects for each performance. Musical experience at the theater can be the basis for musical culture formation because it enhances recognition toward musical as well as increasing individual value creation.

Art management was founded in 60s to enhance marketability of nonprofit arts organizations and arts creation due to their shortage of financial resources in America. Moreover, it was meant to play the role of a medium between divisions as arts was divided into different division and the role of medium grew larger compared to previous individual-centered production system. The role of arts manager as a medium that adjusts creation process to deliver art works clearly to the audience, and interprets the works became important(Yong, 2010).

Currently, Arts \& Cultural Management is recognized as a development from the previous fundraising method. It was to realize artistic qualities, publicity, and financial independency as the center of proper growth and management of institution, and fundamentally vitalize arts organizations and institutions, and contribute to independent consumer culture formation(Park, 2008).

As can be observed, approach to performance is changing from product-centered to sale-centered to consumer-centered. This trend is similar to service dominant logic, which recognizes product as the medium or means to provide fundamental service. Products and service differ only in materiality and immateriality, and form one bundle for the customer's value creation, not separate elements(Kim, 2009). Among servicerelated sectors, service design, unlike existing service-related sectors, takes Manifestation independent approach and understands customer's emotions and actions in integrated perspective and embodies this into service(Service Design Council).

In the changing environment of musical market, service design has fitting characteristic for art management. Service design recognizes audience's emotions, behavior and service process in integrated perspective. Considering the feature of musical, the work of arranging tacit information of audience's experience formation process on performance and performance related services into explicit information is such a work. 
This study will analyze performance experience formation process and variables within overall musical service. This paper is basic study which means to enhance musical experience and suggest planning direction using service design principles.

This study is comprised of following procedure in table 1.

Table 1. Research Phases

\begin{tabular}{|c|c|c|}
\hline Phase 1 & literature study and preceding studies & $\begin{array}{l}\text { studying service design thinking, audience, and the theory } \\
\text { of flow experience }\end{array}$ \\
\hline \multirow[t]{2}{*}{ Phase 2} & extracting musical experience formatio & extracting musical flow model \\
\hline & process and specific elements & extracting specific variables that affect the flow \\
\hline Phase 3 & structure formation & developing structure of experience formation and elements \\
\hline Phase 4 & application direction suggestion & suggesting possibility of expansion \\
\hline
\end{tabular}

First, this paper will study the overall service design thinking, audience, and the theory of flow experience. Second, based on the previously analyzed theory, it will extract specific elements of musical experience formation process. These elements all act as the variables in the experience formation process. Third, the structure of specific elements and basic theory will be formed and visualized. Fourth, possibility of expansion will be suggested considering the formed structure.

\section{Theoretical Background}

\subsection{Service Design}

Service Design Council suggests that service design is the methodology and a field of study that enhances effective and attractive service experience of customer and service supplier by first, finding potential needs of interested parties by utilizing customer-centered contextual research method toward all material and immaterial elements(people, objects, action, emotion, place, communication, diagram, etc) that the customer experiences through the service and all routes(process, system, interaction, emotion road map), and then embodying them in a creative and interdisciplinary and cooperative design method. Stickdorn(2011) argues that service design is interdisciplinary rather than a new independent 'study field', and explains service design with five basic principles of service design thinking.

- User-centered. understanding customer and using appropriate language according to their situation,

- Co-creative. Enabling participation of various interested people including customer in service design process and enhancing the interaction between service and interested people,

- Sequencing. Arranging service flow in a way that best delivers the service,

- Evidencing. Visualizing service that can be immaterial experience,

- Holistic. Understanding the broad context of all process of the service. 


\subsection{Audience}

Customer understanding in service design is closer to real-time communication on all processes of performance with the audience than merely providing appropriate service. Performance experience formation process leads to individual value creation of musical experience, and forms the basis for musical culture formation.

Abercrombie and Longhurst(1998; Kolb, 2000) divided consumers of performance arts to 5 categories according to voluntary community type and media participation as can be seen in table 2; consumer, fan, cultist, enthusiast, and petty producer. These 5 types each have different views on performance. Majority of consumers are those who are not willing to learn musicals (Kolb, 2004).

Table 2. Medium use model

\begin{tabular}{|c|c|c|c|c|c|}
\hline & Consumer & Fan & Cultist & $\begin{array}{l}\text { Petty } \\
\text { er }\end{array}$ & Produc- \\
\hline & average customer & & professional customer & amateu & ur producer \\
\hline Emotion & fun & & & serious interest & \\
\hline Frequency & low frequency & & high frequency & & \\
\hline $\begin{array}{l}\text { Approach } \\
\text { method }\end{array}$ & choose freely & $\begin{array}{l}\text { choose based } \\
\text { on experience }\end{array}$ & & $\begin{array}{l}\text { approach as a form of art. } \\
\text { enjoy most types. }\end{array}$ & \\
\hline $\begin{array}{l}\text { Choice } \\
\text { criteria }\end{array}$ & Accessibility, cost & Star, program & & & \\
\hline Community & & & social activity & organizational activity & occupation \\
\hline $\begin{array}{l}\text { Probing } \\
\text { action and } \\
\text { Knowledge } \\
\text { level }\end{array}$ & & $\begin{array}{l}\text { bear additional } \\
\text { cost and } \\
\text { inconvenience }\end{array}$ & $\begin{array}{l}\text { researching star } \\
\text { and publication } \\
\text { visiting related } \\
\text { historical sites }\end{array}$ & $\begin{array}{l}\text { high level of contents and } \\
\text { producer knowledge }\end{array}$ & \\
\hline
\end{tabular}

Domestically, research on musical audiences has been done in the perspective of lifestyle, audience division, and consuming tendency(Kang and Lee, 2001: Ko and Park, 2008: Hyun and Kang, 2012).

\section{Musical Experience Formation Model Structure}

\subsection{Purchase Stages}

There are five stages in purchase: problem recognition, information search, evaluation of alternative products, product purchase, post-purchase product evaluation(Lamb, Hair, and McDaniel, 1999). Table 3 shows details about musical experience based on these five stages. In the problem recognition stage, the reason for enjoying a performance, what is to be achieve from watching the performance, and what the audience wants is to be perceived. They pursue mental satisfaction, want to enjoy cultural life, and refresh themselves(Kang and Lee, 2001).

Audiences search for events that can satisfy their needs in information search. They have access to information such as summary, contents, commentary, cast, synopsis, making story, reservation and contact number from various promotion, media, broadcast and internet(Jeon, 1999). When sufficient information is gathered, the audience chooses performances by evaluating alternatives according to their preferred 
standards, and purchases the products through reservation. This process exists also after the reservation is done. This level ends after enjoying the performance and evaluating the product.

Table 3. Stages of purchase about booking musical ticket

\begin{tabular}{|c|c|c|c|c|}
\hline Problem recognition & \multicolumn{4}{|c|}{$\begin{array}{l}\text { What is to be done? } \\
\text { Reason for consumption_leisure, entertainment, custom, self-improvement } \\
\text { Convenience_mental satisfaction, cultural life, refreshing }\end{array}$} \\
\hline \multicolumn{2}{|l|}{ Information search } & $\begin{array}{l}\text { Alterna- } \\
\text { tive evalu- } \\
\text { ation }\end{array}$ & $\begin{array}{l}\text { Product pur- } \\
\text { chase }\end{array}$ & On the spot \\
\hline product characteristic & information source & standard & \multirow{9}{*}{$\begin{array}{l}\text { booking } \\
\text { reservation by phone } \\
\text { on the spot reserva- } \\
\text { tion } \\
\text { group reservation } \\
\text { reserved ticket } \\
\text { invitation }\end{array}$} & \multirow{2}{*}{$\begin{array}{l}\text { receiving ticket_ } \\
\text { receiving on the spot } \\
\text { mail delivery }\end{array}$} \\
\hline $\begin{array}{l}\text { original work, } \\
\text { history, background } \\
\text { content_theme, sub topic } \\
\text { Song__OST, features }\end{array}$ & $\begin{array}{l}\text { poster } \\
\text { leaflet } \\
\text { ticket } \\
\text { pamphlet }\end{array}$ & $\begin{array}{l}\text { format } \\
\text { content } \\
\text { level } \\
\text { quality }\end{array}$ & & \\
\hline $\begin{array}{l}\text { producer- } \\
\text { writer, director, lyricist, } \\
\text { composer, choreographer }\end{array}$ & \multirow[t]{2}{*}{$\begin{array}{l}\text { banner } \\
\text { footbridge signboard } \\
\text { vehicle AD } \\
\text { electronic display }\end{array}$} & $\begin{array}{l}\text { production } \\
\text { cast }\end{array}$ & & \multirow[t]{2}{*}{$\begin{array}{l}\text { related purchase_ } \\
\text { program book } \\
\text { OST } \\
\text { promotion products }\end{array}$} \\
\hline cast_actor, ensemble & & venue & & \\
\hline scale & \multirow{2}{*}{$\begin{array}{l}\text { newspaper, magazine } \\
\text { TV, Radio }\end{array}$} & $\begin{array}{l}\text { location } \\
\text { seat }\end{array}$ & & \multirow[t]{5}{*}{ opera glasses rent } \\
\hline location characteristic & & & & \\
\hline $\begin{array}{l}\text { venue, location } \\
\text { theater structure } \\
\text { seat arrangement } \\
\text { parking lot } \\
\text { additional facilities }\end{array}$ & \multirow{3}{*}{$\begin{array}{l}\text { official homepage } \\
\text { Social Media } \\
\text { affinity society } \\
\text { fanclub } \\
\text { personal blog } \\
\text { rumor }\end{array}$} & $\begin{array}{l}\text { prior know- } \\
\text { ledge } \\
\text { expert }\end{array}$ & & \\
\hline schedule & & evaluation & & \\
\hline \multicolumn{2}{|l|}{ additional service } & & & \\
\hline Product Evaluation & \multicolumn{4}{|c|}{$\begin{array}{l}\text { Was the performance experience in consistent with the expected benefit? } \\
\text { Did it satisfy the expectation? }\end{array}$} \\
\hline
\end{tabular}

The standard for alternative evaluation is similar to the contents of information search, and table 4 shows the standard applied in previous studies.

Table 4. standard for alternative evaluation in previous studies

\begin{tabular}{lll}
\hline Author & Object & Standard \\
\hline $\begin{array}{l}\text { Kang and Lee } \\
(2001)\end{array}$ & musical audience & $\begin{array}{l}\text { cast, contents, summary, reputation of the work, nationality of the work, } \\
\text { production and planning, admission fee, recommendation, venue, expert } \\
\text { evaluation, sponsor }\end{array}$ \\
\hline $\begin{array}{l}\text { Kim, S., Kim, Y. } \\
\text { and Kwak }\end{array}$ & audience & $\begin{array}{l}\text { performance genre, characteristic of the work, selling point, additional } \\
\text { service, venue, ticket price }\end{array}$ \\
\hline Kolb (2004) & consumer & cost, value, satisfaction \\
\hline $\begin{array}{l}\text { Ko and Park } \\
(2008)\end{array}$ & $\begin{array}{l}\text { Musical perfor- } \\
\text { mance audiences in } \\
\text { online community }\end{array}$ & $\begin{array}{l}\text { venue, seat, cast and director, performance genre and type, contents, } \\
\text { previous knowledge on the performance, quality of the performance, } \\
\text { ticket price, venue surroundings, customer service and management }\end{array}$ \\
\hline $\begin{array}{l}\text { Hyun and Kang } \\
\text { (2012) }\end{array}$ & culture consumer & $\begin{array}{l}\text { applying marketing 7P mix strategy } \\
\text { price(admission fee, discount), promotion(convenient access to tickets, } \\
\text { ADs), distribution(location accessibility), product(degree of completion, } \\
\text { easy to understand, famous, creative), people(production crew, staff, actor), } \\
\text { physical evidence(comfort of the seat, resting place, lighting, sound } \\
\text { system, parking, performance facilities), process(program) }\end{array}$ \\
\hline
\end{tabular}




\subsection{Flow Experience}

Csikszentmihalyi(1975) first introduced the concept of flow, which is the mental state of operation in which a person performing an activity is fully immersed in a feeling of energized focus, full involvement, and enjoyment in the process of the activity.

Jee and Kim(2009) suggested a study model that broadly applies the background variables of flow, antecedent variables, and dependent variables of musical based on study done by Novak, Hoffman and Yung(2000), which is recognized as the key study model.

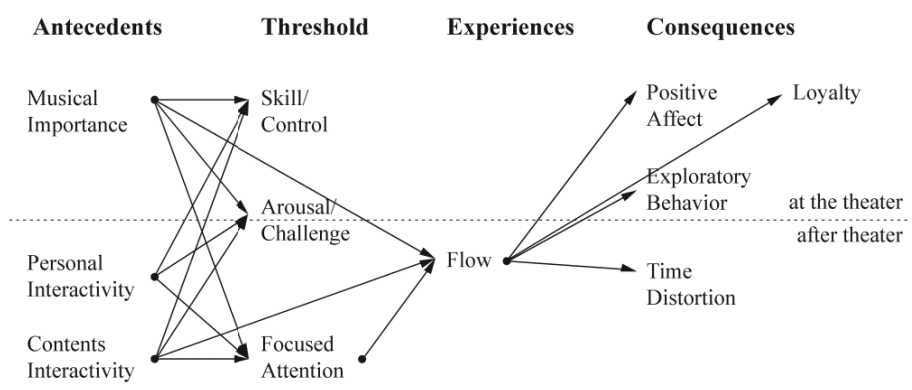

Fig. 1. Structural Model of Musical Audience's Flow Experience(Source: Jee and Kim, p. 107)

As the result, the model was tested holding musical involvement/importance, personal(audience) interactivity, contents interactivity as antecedents, skill/control, arousal/challenge, focused attention as threshold, and positive affect, exploratory behavior, time distortion as consequences. The flow in performance has impact on time distortion, positive affect, exploratory behavior and loyalty, and is affected by the importance, contents interactivity and focused attention. Contents interactivity is related to the connection between the audience and each elements of the musical which are script, lyrics, music, dance, direction, actor, and acting. In order to facilitate contents interactivity during the performance, the audience must be able to choose musicals matched their desired contents.

Because musical has high price level than other alternatives such as plays and movies, it is important that the audiences watch musicals that match their personal taste in order to for a pleasant experience of musical. Consumers usually watch musicals for pleasure and their standard for musical choice is convenience and cost, not professional knowledge. However, musical is an integrated stage art, and a lot of professional knowledge is needed to choose an appropriate musical for oneself, because the overall type of musical changes depending on the forms of musical elements such as script, lyric, music, dance, and direction. This makes it difficult for the each audience to choose the best musical experience that he or she prefers.

Moreover, consumer, fan, and those above cultists all have different eyes for a musical while all of these form characteristics of musical. Therefore, musical information is needed to find out what kind of people placed more importance on which characteristics, and to learn what their standards were. 


\subsection{The relationship between Musical Contents}

Musical knowledge is divided according to different levels described below in table 5 .

Table 5. Product Knowledge Level on Musical

\begin{tabular}{lllll}
\hline Product Class & Product Form & Brand & Model/ Features & \\
\hline Musical & Live & Producer & Book Show & Writer \\
& Live recording & Drama company & Concept musical & Composer \\
& Live concert & Concert hall & Dramacal & Lyricist \\
& Concert recording & & Jukebox Musical & Director \\
& Musical movie & & Moviecal & Choreographer \\
& & & Nonverbal performance & Actor \\
& & & Novelcal & Program \\
& & & Small theater musical & \\
\hline
\end{tabular}

Because musical has heterogeneity, same performance can give different impression depending on the actors. And different contents can give similar impressions when watching performances by same composer or actors. Thus, connections can be created in the process of forming musical experience from one musical to another. In other words, depending on the type of musical information contents, various relationships are possible between musicals and between contents.

For example, in 2012 Tom Hooper's Les Miserables was released in the Korean market. Before its release, the figure skating champion Kim Yuna used the song edited from the musical Les Miserables in her performance, which introduced Les Miserables to a large number of people. When the movie was released, the popularity of the premiere Korean musical Les Miserable which started before the release, increased. At the same time, the novel Les Miserables and its author Victor Hugo drew attention. Interest toward the musical numbers of Les Miserables increased, and numerous parodies were created, the most famous one being the Les Militaribles produced by air force band and media video team which hit 4 million views on Youtube.
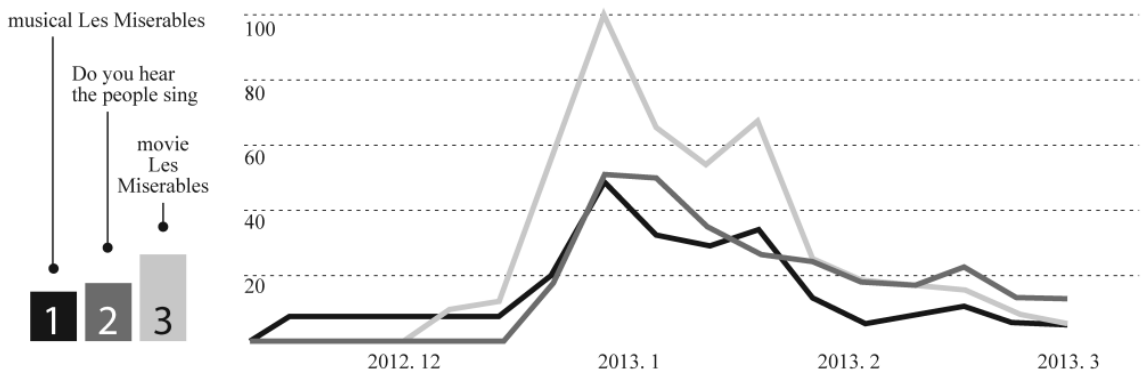

Fig. 2. Google Trend Search (musical, musical number, movie)

This can be observed in google trend search which helps comparing proportions of search words as well. This graph shows the ratio of search keywords in Korean google. Black(1) shows the musical Les Miserables, dark gray(2) represents famous one of the Les Miserables' musical number, and light gray(3) is the movie Les 
Miserables. The frequency of searching the musical Les Miserables increased after the performance started in November. The movie Les Miserables was released on December 18th, and the frequency of searching for the movie increased in December, reaching its peak one week after the release. Although there was no significant change regarding the musical Les Miserables in the last week of December, the frequency for searching for it increased with the release of the movie. 'Do You Hear the People Sing' received the same level of attention as the musical Les Miserables during the same period. The middle of January, which is the second peak, is the time when Les Miserables OST won the first place in the weekly Billboard chart.

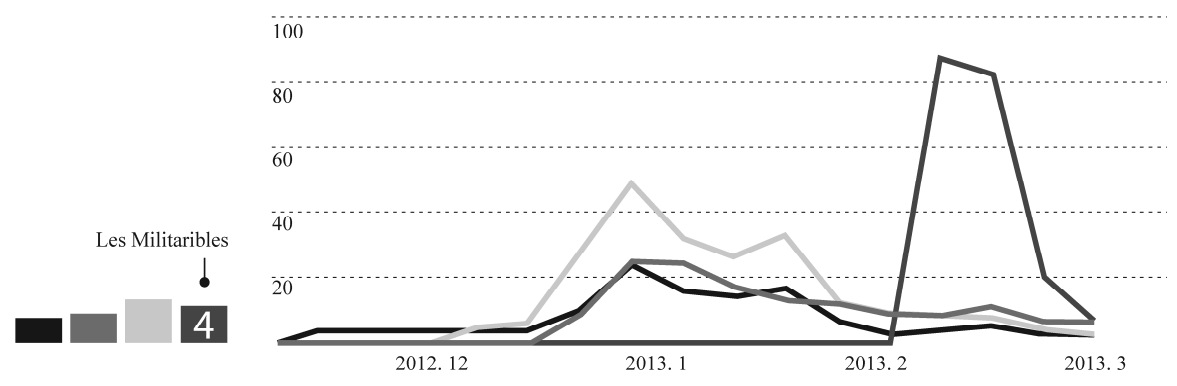

Fig. 3. Google Trend Search (musical, musical number, movie, parody)

Forth one represents Les Militaribles. The graph shows that after Les Militaribles was uploaded on Youtube, the frequency of the search for the musical, 'Do You Hear the People Sing', and the movie all increased. This shows that musical Les Miserables and its various contents were recognized in relation to each other. Thus musical information is more efficiently utilized when arranged together with structure.

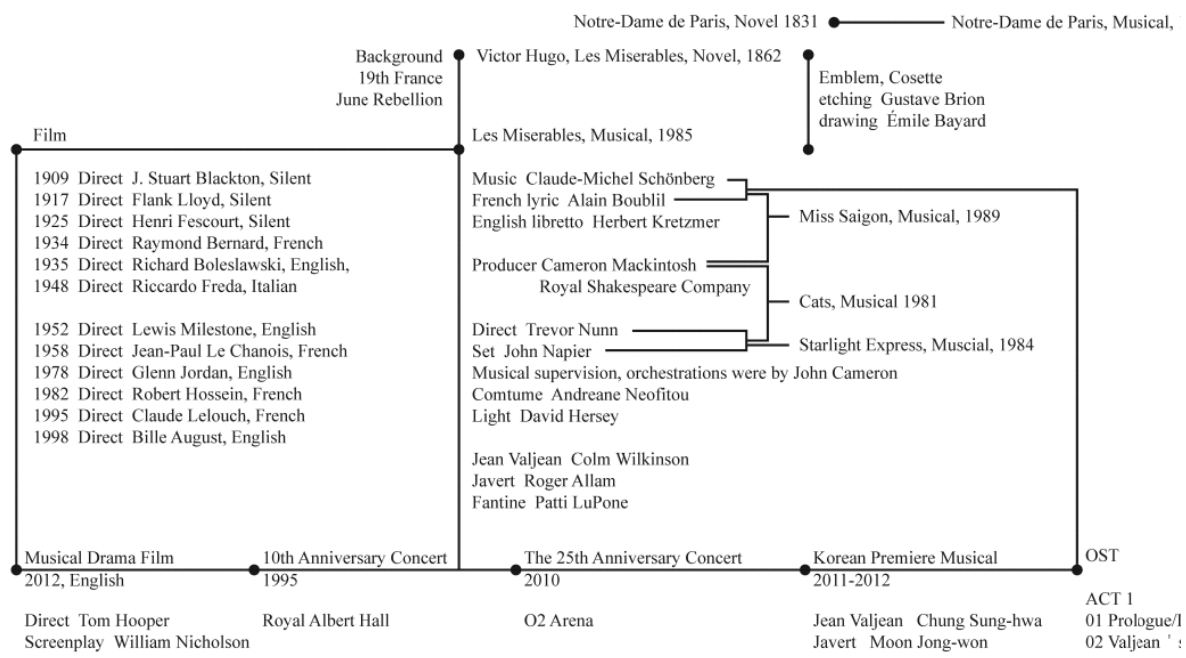

Fig. 4. Contents Map for Musical Les Miserables 
As can be seen in figure 4 , the musical Les Miserables is connected to premiere musical, Victor Hugo's original novel, OST, musical live concert video, Korean premiere musical and musical movie with same contents. The premiere musical Les Miserables is one of the big 4 which is comprised of Miss Saigon, Cats, and Phantom of the Opera, and can be connected to Miss Saigon by composer and lyricist, Cats and Starlight Express by stage and director. The original author Victor Hugo can be reached by three different types of translation in domestic market, and another dramatized work of his is Notre-dame de Paris. There are two types of the musical concert Les Miserables: the 10th anniversary and the 25th anniversary version. The movie Les Miserables can be compared to other movies that were previously filmed.

Accordingly, people who are interested in the musical Les Miserables can broaden their understanding of it or expand their interest to other works by taking those routes mentioned above. Figure 4 shows twice contents expansions from the elements of the original musical Les Miserables as the base. Because the standards are the musical elements, this data shows the audience's expansion of knowledge on the musical. If the producer was the standard and the contents expansion is progressed without setting limits, the information structure of the relationship between musicals of different producers can be found. Depending on the standards, the contents expansion can happen not only between musicals but also novels, movies, concert videos, OST, historical backgrounds, and etc.

\section{Conclusion}

This study defined and arranged elements that affect musical experience formation model and musical experience in various perspectives. It started from the effort to understand the experience of the audience by arranging them in the perspective of service design thinking. Then, it found the context existing in the relationship between purchase level, flow experience process, and contents relationship of the musical experience service, and visualized them in material form after arranging them. This expands the range of service design thinking to musical experience which is a form of popular arts, and can be used as basis for finding directions in understanding musical art management in design perspective through expansion of integrated thinking.

This study has two limitations. Although elements of musical experience were analyzed, whether each elements have meaningful effect on consumer experience formation when such relationship was formed, or whether there are meaningful or meaningless elements depending on the type of the consumer are not verified through experiments. Therefore, additional study on the definition and application of elements is needed.

Moreover, although this data was compiled by applying service design perspective, only surface levels are dealt with, without considering the psychology of the audience toward each situations or background to each experience situation. Thus, only basic parts of the study for applying service design to art management. 


\section{References}

1. Choi, S.Y.: A Study on Aspects of the Performance of Musical Theatre in Korea from 1990 to 2000. Journal of Korean Theater Studies Association 29, 263-291 (2006)

2. Hyun, J., Kang, S.K.: Market Segmentation for Culture Facilities According to Culture Consumption Pattern and Lifestyle. Review of Cultural Economics 15(20), 79-101 (2012)

3. Jee, J.E., Kim, S.Y.: A Study on the Structural Model of Flow Experience Among Musical Audience 2(12), 87-114 (2009)

4. Kang, G.D., Lee, J.H.: An Exploratory Study on the Life-style of Audience for Culture and Art Performance. Korean Management Review 30(4), 1143-1167 (2001)

5. Kim, S.Y., Kim, Y.J., Kwak, Y.S.: Marketing Segmentation by Mixture Model for Cultural \& Art Institutions. The Korean Journal of Advertising 14(5), 49-74 (2003)

6. Kim, Y.J.: Service Innovation, Way to dominate the Market. Dong-A Business Review 28, 66-69 (2009)

7. Ko, J.M., Park, S.Y.: Analysis in Community Activities and Watching Behavior of Musical Performance Audiences in Online Community. Review of Cultural Economics 11(1), 33-59 (2008)

8. Lee, S.Y.: A Study on Role Adjustment and Combination in Korean Performing Arts. Review of Cultural Economics 5(2), 23-45 (2002)

9. Park, S.E.: Arts \& Cultural Management, Prospective View in 21st Century of Theoretical Basis and Practice. Journal of Arts and Cultural Management 1, 205-214 (2008)

10. Abercrombie, N., Longhurst, B.: Audiences: A Sociological Theory of Performance and Imagination. Sage, London (1998)

11. Csikszentmihalyi, M.: Beyond Boredom and Anxiety: Experiencing Flow in Work and Play. Jossey-Bass, San Francisco (1975)

12. Jang, H.J.: Performance Planning. In: Lee, G.S., Lee, S.H. (eds.) Performing Art. Geulnuri, Daejeon (2007)

13. Jeon, S.H.: Performance Planning Handbook. Jeyoung Communications, Seoul (1999)

14. Kolb, B.M.: Marketing Cultural Organizations, Oak Tree, Cork (2000)

15. Lamb, C., Hair, J., McDaniel, C.: Essentials of Marketing. Southwestern College Publishing (1999)

16. Lee, I.G.: Management of Performing Arts. Adbooks, Seoul (2009)

17. Stickdorn, M., Schneider, J. (eds.): This is Service Design Thinking. BIS, Amsterdam (2011)

18. Yong, H.S.: Arts Management. Gimmyoung, Paju (2010)

19. Google Trend, http://www.google.com/trends/explore?hl=ko\#q=\%EB\% $\mathrm{AE} \% \mathrm{~A} 4 \% \mathrm{EC} \% \mathrm{~A} 7 \% 80 \% \mathrm{EC} \% \mathrm{BB} \% \mathrm{AC} \% 20 \% \mathrm{~EB} \% \mathrm{~A} 0 \% 88 \% \mathrm{~EB} \% \mathrm{AF} \% \mathrm{~B} 8 \% \mathrm{EC} \% \mathrm{~A} 0 \% 9 \mathrm{C} \% \mathrm{~EB} \% 9 \mathrm{D} \%$ $\mathrm{BC} \% \mathrm{~EB} \% \mathrm{~B} 8 \% 94 \% 2 \mathrm{C} \% 20$ do\% 20 you 20 hear 20 the 20 people $\% 20$ sing $\% 2 \mathrm{C} 20$ $\% \mathrm{EC} \% 98 \% 81 \% \mathrm{ED} \% 99 \% 94 \% 20 \% \mathrm{~EB} \% \mathrm{~A} 0 \% 88 \% \mathrm{~EB} \% \mathrm{AF} \% \mathrm{~B} 8 \% \mathrm{EC} \% \mathrm{~A} 0 \% 9 \mathrm{C} \% \mathrm{~EB} \% 9 \mathrm{D} \% \mathrm{BC} \% \mathrm{~EB}$ $\% B 8 \% 94 \& g e O=K R \& d a t e=11 \% 2 F 2012 \% 205 m \& \mathrm{cmpt}=q$

20. Interpark Performance Settlement of Accounts, http://incorp.interpark.com/ communication/PressNewsListMgt.do?_method=list

21. Service Design Council, http: //www. servicedesign.or.kr 